\title{
PRODUCTION OF FUMONISINS BY STRAINS OF FUSARIUM MONILIFORME ACCORDING TO TEMPERATURE, MOISTURE AND GROWTH PERIOD
}

\author{
Paulo Dilkin; Carlos A. Mallmann*; Carlos A.A. de Almeida; Eliza B. Stefanon; Fernanda Z. Fontana; \\ Elisane L. Milbradt
}

Departamento de Medicina Veterinária Preventiva, Universidade Federal de Santa Maria, Santa Maria, RS, Brasil

Submitted: June 21, 2001; Returned to authors for corrections: October 10, 2001; Approved: June 10, 2002

\begin{abstract}
Production of fumonisins $\mathrm{B}_{1}\left(\mathrm{FB}_{1}\right)$ and $\mathrm{B}_{2}\left(\mathrm{FB}_{2}\right)$ by two Brasilian strains (LAMIC 2999/96 and $\left.113 \mathrm{~F}\right)$ and one American strain (NRRL 13616) of Fusarium moniliforme were evaluated in laboratory cultures subjected to different temperatures $\left(20,25\right.$, and $\left.30^{\circ} \mathrm{C}\right)$, and moisture contents $(25,34$, and $42 \%)$ on corn substrate. The cultures were grown during 10,20,30,45, and 60 days, totalizing 135 treatments with two repetitions for each one. The fumonisins were extracted with acetonitrile/water. The clean-up with end-capped $\mathrm{C}_{18}$ silica $\left(\mathrm{C}_{18 \mathrm{ec}}\right)$ cartridges and fumonisin derivatization with $o$-phtaldialdeyde were carried out through an automated sample processor system (ASPEC), followed by quantification of the toxins through HPLC. Fumonisin production varied widely, reaching average yields from 0.25 to $5515.45 \mu \mathrm{g} / \mathrm{g}$ of $\mathrm{FB}_{1}$ and from 0.15 to $3032.10 \mu \mathrm{g} / \mathrm{g}$ of $\mathrm{FB}_{2}$. In the present work, the factors strain, temperature, moisture and days of fungal culture were evaluated, and all of them had a bearing on the amounts of fumonisins produced. The highest $\mathrm{FB}_{1}$ average yields were obtained by the strain $113 \mathrm{~F}$, under the following conditions: $34 \%$ moisture content, 60 culture days, and temperature of $25^{\circ} \mathrm{C}$. The highest $\mathrm{FB}_{2}$ average yield was obtained by the same strain with cultures over 45 days, $42 \%$ moisture content, at the temperature of $25^{\circ} \mathrm{C}$. Via regression analysis, the ideal temperature for fumonisins production was, calculated as 24.5 and $24.3^{\circ} \mathrm{C}\left( \pm 2^{\circ} \mathrm{C}\right)$ for $\mathrm{FB}_{1}$ and $\mathrm{FB}_{2}$, respectively.
\end{abstract}

Key words: Fungi, Fusarium moniliforme, mycotoxins, fumonisins, abiotic factors.

\section{INTRODUCTION}

Fumonisins belong to a large group of toxic metabolites produced by fungi of the genera Fusarium $(19,26)$ and Alternaria (4). These are natural contaminants of cereals worldwide and are mostly found in corn and corn-based products $(9,30,32)$. The occurrence of fumonisin $\mathrm{B}_{1}\left(\mathrm{FB}_{1}\right)$ in Brazilian feeds was demonstrated by several investigations $(6,9,15,21,32)$.

The $\mathrm{FB}_{1}$ is the most abundant and toxic metabolite of this group of mycotoxins, representing $c a .70 \%$ of the total concentration in naturally contaminated foods and feeds, followed by fumonisins $\mathrm{B}_{2}\left(\mathrm{FB}_{2}\right)$ and $\mathrm{B}_{3}\left(\mathrm{FB}_{3}\right)(18,20,23)$. Their action is characterized by inhibition of de novo sphingolipid biosynthesis and consequent elevation in the ratio of sphinganine and sphingosine in serum of exposed animals (40). Fumonisins are known to be toxic to domestic animals and to induce leukoencephalomalacia in horses (12) and porcine pulmonary edema (22). Liver hyperplastic nodules and lesions in the distal esophageal mucosa of weaning pigs fed with fumonisincontaminated feed have also been reported (3). These micotoxins also caused reduced body weight gain in chicks and turkey polts $(14,39)$ and pigs (3). Additionally, epidemiological studies have shown a positive association between exposure to dietary fumonisin and increased risk of human esophageal cancer $(5,24,35)$.

\footnotetext{
* Corresponding author. Mailing address: Departamento de Medicina Veterinária Preventiva, Universidade Federal de Santa Maria, Campus Camobi, Prédio 44.97105-900, Santa Maria, RS, Brasil. Fax: (+5555) 220-8445. E-mail: mallmann@ccr.ufsm.br
} 
The production of fumonisins in agricultural commodities depends on such factors as geographical region, season, and the environmental conditions under which the particular grain grows, is harvested and stored. Tropical and subtropical regions are the most favorable for fungi development on cereals and production of these toxins (36). Although cereals are important as substrates, moisture level and temperature are the critical abiotic factors regulating the growth of Fusarium moniliforme and the production of fumonisins (2). Low kernel moisture content $<22 \%$ should reduce or prevent toxin production in storage (13). Information on the minimal, optimal, and maximum temperature for fumonisin production is uncertain; however, the best temperature range for fumonisin production is $20-28^{\circ} \mathrm{C}$ (1). Ryu et al. (28) investigated the influence of the temperature and its variations on the $\mathrm{FB}_{1}$ production. They also tested the effect of cyclic temperatures at intervals of 12 hours on cultures kept at 5 and $25^{\circ} \mathrm{C}, 10$ and $25^{\circ} \mathrm{C}$, and 15 and $30^{\circ} \mathrm{C}$. In addition, they carried out tests on cultures at constant temperature $\left(25^{\circ} \mathrm{C}\right)$ for two weeks followed by four more weeks at $15^{\circ} \mathrm{C}$. In all cultures $\mathrm{FB}_{1}$ production was observed, however, the highest average was obtained from samples cultured at cyclic temperatures of 10 and $25^{\circ} \mathrm{C}$.

Marín et al. (16) surveyed the effects of different temperatures $\left(25\right.$ and $\left.30^{\circ} \mathrm{C}\right)$ and water activities $(0.968,0.956,0.944,0.925)$ on fungal growth and fumonisin production by Fusarium moniliforme and Fusarium proliferatum strains, observing that both increased as the moisture and temperature increased. By evaluating the effect of $\mathrm{pH}(3.6,5.5$, and 7.0$)$ and temperature (4$45^{\circ} \mathrm{C}$ ) on the fungal growth, Marín et al. (17) concluded that Fusarium monoliforme grew better at $\mathrm{pH} 7.0$ and $30^{\circ} \mathrm{C}$, whereas Fusarium proliferatum grew better at $\mathrm{pH} 5.5$ and $25^{\circ} \mathrm{C}$.

On harvested samples, the concentration of fumonisins is usually lower than $10 \mu \mathrm{g} / \mathrm{g}$. Yet, more than two thirds of these samples are positive for such toxins $(8,9,30,34)$. However, very high $\mathrm{FB}_{1}$ concentrations such as 126 and $330 \mu \mathrm{g} / \mathrm{g}$ have already been found in foods (27).

Under laboratory conditions, high concentrations of fumonisins can be obtained inoculating Fusarium moniliforne onto sterile corn with high moisture content. The amount of fumonisin is also dependent upon the strain of Fusarium moniliforme employed in the culture $(19,37,38)$. Hence, fumonisin concentrations can be above $10000 \mu \mathrm{g} / \mathrm{g}$ in 13-week culture medium $(1,10)$.
The present work describes the influence of abiotic factors such as moisture, culture time and temperature on production of fumonisins, using three strains of Fusarium moniliforme, 1) LAMIC 2999/96, isolated from a corn sample naturally contaminated with $\mathrm{FB}_{1}$ and $\mathrm{FB}_{2}$, responsible for an outbreak of horse leukoencephalomalacia in Catuípe's municipal districtRS (15); 2) NRRL 13616, from USA; and 3) 113F, from the Universidade Estadual de Londrina-PR. The choice of such strains was done because they are admittedly high fumonisin producers, according to tests carried out previously.

\section{MATERIALS AND METHODS}

\section{Fumonisin production}

The fungus isolation and maintainance were carried out according to Mallmann et al. (15).

The methodology employed for fumonisin production was adapted from several authors $(1,10,19)$. Corn grains with $11.9 \%$ moisture content were utilized to prepare the fungal cultures.

The experiment was outlined with two repetitions of 135 treatments consisting of three strains of Fusarium moniliforme, which were evaluated at different culture periods: 10, 20, 30, 45 and 60 days, with 25,34 and $42 \%$ moisture content on the substrate, and cultured at temperatures of 20,25 , and $30^{\circ} \mathrm{C}$ as shown in Table 1.

For fumonisin production, the following procedures were adopted for each treatment: $100 \mathrm{~g}$ of corn with $11.9 \%$ moisture content was weighed in triplicate, in $500 \mathrm{ml}$ Erlenmeyer flasks. To each weighed amount deionized water was added (10.2, 18.1 and $25.2 \mathrm{ml}$, respectively) in order to obtain corn samples with 25,34 and $42 \%$ moisture content, respectively. The flasks were closed with cotton tops. The samples were allowed to stand on shelves for two hours at room conditions, and ten autoclaved for 20 minutes. Thirty minutes later, $0.5 \mathrm{ml}$ of potato dextrose agar containing Fusarium moniliforme culture was added to each sample. The flasks were closed again, and shaken manually to homogenize the culture material. They were then covered with aluminium foil and placed in BOD incubator. On the third incubation day, the cultures were vigorously shaken in order to get a better fungus distribution on the samples. After the culture period, the material was autoclaved for 5 minutes, dried in an electrical oven at $45^{\circ} \mathrm{C}$ during 15 hours, and ground and stored in freezer at $-18^{\circ} \mathrm{C}$ until quantification of fumonisins.

Table 1. Experimental outline of culture of 3 strains of Fusarium moniliforme.

\begin{tabular}{lllllllllllllllll}
\hline Culture days & & 10 & & & 20 & & & 30 & & 45 & & 60 \\
\hline Moisture $(\%)$ & 25 & 34 & 42 & & 25 & 34 & 42 & 25 & 34 & 42 & 25 & 34 & 42 & 25 & 34 & 42 \\
& 20 & 20 & 20 & & 20 & 20 & 20 & 20 & 20 & 20 & 20 & 20 & 20 & 20 & 20 & 20 \\
Temperature $\left({ }^{\circ} \mathrm{C}\right)$ & 25 & 25 & 25 & 25 & 25 & 25 & 25 & 25 & 25 & 25 & 25 & 25 & 25 & 25 & 25 \\
& 30 & 30 & 30 & 30 & 30 & 30 & 30 & 30 & 30 & 30 & 30 & 30 & 30 & 30 & 30 \\
\hline
\end{tabular}




\section{Standards}

Standards of fumonisins $\mathrm{B}_{1}\left(\mathrm{FB}_{1}\right)$ and fumonisina $\mathrm{B}_{2}\left(\mathrm{FB}_{2}\right)$ were from Sigma Chemical (St. Louis, USA). Stock standard solutions were prepared in acetonitrile/Milli-Q water (50:50, v/ v) at $1-5 \mathrm{mg} / \mathrm{ml}$. Working standard solutions were prepared in acetonitrile/Milli-Q water (50:50, v/v) at $5 \mu \mathrm{g} / \mathrm{ml}$. All standard solutions were stored at $-18^{\circ} \mathrm{C}$ until use.

\section{Extraction, clean-up and derivatization}

The procedures of extraction and preparation of mycotoxins took place according to previously described methodologies $(25,31,33)$, yet with some slight modifications. Clean-up, derivatization and injection procedures were carried out through an automated sample preparation system (ASPEC) (Gilson-Vivier le Bel, France). Samples $(10 \mathrm{~g})$ were suspended in $50 \mathrm{ml}$ of acetonitrile/water (50:50, v/v) and extracted in a blender (Walita - São Paulo, Brazil) at high speed, for $5 \mathrm{~min}$. Each mixture was filtered through Whatman IV filter paper. Two $\mathrm{ml}$ of acetonitrile/ water extract were mixed with $6 \mathrm{ml}$ of destiled water for clean-up with $300 \mathrm{mg} \mathrm{C}_{18 \mathrm{ec}}$ silica disposable extraction cartridges (DEC). Before clean-up, the sample $\mathrm{pH}$ was adjusted to 5.8-6.5 with 1 $M$ sodium hydroxide when necessary.

The solid phase clean-up, derivatization and injection procedures were performed using ASPEC. The sequence of operations for the automated clean-up of samples was as follows: 1) Condition DEC with $2 \mathrm{ml}$ of acetonitrile. 2) Condition DEC with $2 \mathrm{ml}$ of water. 3) Push $8 \mathrm{ml}$ of sample through DEC (2 ml sample and $6 \mathrm{ml}$ distilled water). 4) Rinse needle. 5) Wash DEC with $5 \mathrm{ml}$ of water. 6) Elute mycotoxins with $2 \mathrm{ml}$ of acetonitrile/ water (70:30, v/v), pH 5.8-6.5. 7). Flow rates through DEC were set at $2 \mathrm{ml} / \mathrm{min}$; however, pushing of sample and eluting procedures were performed with flow rate at $1 \mathrm{ml} / \mathrm{min}$.

The ASPEC was programmed to advance to derivatization and injection of samples after each elution, according to the following procedure: 1) Rinse needle. 2) Dispense $200 \mu 1$ of OPA solution (Dissolve $40 \mathrm{mg}$ of $o$-phthaldialdehyde in $1 \mathrm{ml}$ of methanol and dilute with $5 \mathrm{ml} 0.1 \mathrm{M}$ sodium tetraborate. Add 50 $\mu 1$ of 2-mercaptoethanol) into a clean sample tube conditioned in a temperature-controlled rack at $30^{\circ} \mathrm{C}$. 3) Rinse needle. 4) Add $50 \mu 1$ of test solution. 5) Mix derivative solution (by aspersion and dispense). 6) Rinse needle. 7) Wait for a period of $2 \mathrm{~min} .8$ ) Inject $100 \mu \mathrm{l}$ in the chromatography system. 9) Rinse needle. 10) Rinse injection port. 11) End.

A second derivatization program was used to set up the standard injection and construct a calibration curve. The delivery of OPA and test solutions were conducted at $3 \mathrm{ml} / \mathrm{min}$.

\section{Fumonisin determination by HPLC}

The HPLC consist of a GBC Scientific Equipment pump Model LC 1150 (ICI Instruments - Dingley, Australia) on-line with ASPEC. The mobile phases were composed of acetonitrile/ water/acetic acid (50:50:1, v/v), (solution A) with a linear gradient of acetonitrile (solution B) according to Chu and $\mathrm{Li}$ (5) and Stack and Eppley, (31), with some modifications. For the first 8 minutes of the chromatographic run, the mobile phase consisted of $100 \%$ solution $\mathrm{A}$, at which time a step change was made to $85 \%$ solution A and $15 \%$ solution $\mathrm{B}$. The mobile phase then returned to $100 \%$ solution $\mathrm{A}$ by means of a linear gradient over a 4-minute period. These mobile phases were filtered through a $0.45 \mu \mathrm{m}$ Waters $\mathrm{HV}$ membrane and pumped at $1 \mathrm{ml} / \mathrm{min}$ flow rate over the entire chromatogram. The chromatographic column, 150 x $4.6 \mathrm{~mm}$, ODS, $5 \mu \mathrm{m}$, Macherey-Naguel (Düren, Germany) was maintained at a constant temperature of $35^{\circ} \mathrm{C}$ in a column oven. Fumonisins were detected by a fluorescence detector (F100, Merck - Schuchardt) with wavelength set at $335 \mathrm{~nm}$ for excitation and $440 \mathrm{~nm}$ for emission. Calculation of fumonisin concentrations in test samples was based on peak areas compared with those of the standards. The limits of quantification of the method were of 20 and $30 \mu \mathrm{g} / \mathrm{kg}$ for $\mathrm{FB}_{1}$ and $\mathrm{FB}_{2}$, respectively.

\section{Statistical analysis}

The experimental outline utilized for fumonisin production was entirely random in a factorial experiment based on $3 \times 3 \times 3$ x 5 ( 3 strains, 3 temperatures, 3 moisture contents, and 5 culture periods), totalizing 135 treatments with two repetitions for each one. The global statistical analysis on fumonisin production data was performed after transformation of their numerical values into decimal logarithm scale. The fumonisin production was then analyzed through analysis of variance (ANOVA) method so that the effects of the interaction of a single factor such as temperature $(\mathrm{T})$ culture days $(\mathrm{C})$, strain $(\mathrm{L})$, and moisture content (U), and of two-factor (T x C, T x L, T x U, C x U, C x L, L x U), and three factors ( $\mathrm{T} \times \mathrm{C} \times \mathrm{L}, \mathrm{T} \times \mathrm{C} \times \mathrm{U}, \mathrm{T} \times \mathrm{L} \times \mathrm{U}, \mathrm{C} \times \mathrm{L} \times \mathrm{U}$ ) on fumonisin production might be evaluated. In a unique case, the four-factor interaction ( $\mathrm{T} \times \mathrm{C} \times \mathrm{L} \times \mathrm{U}$ ) was also evaluated. Tukey test $(p<0.05)$ was applied for comparison of the averages. Polynominal regression studies were effected analyzing models of first and second degrees (linear and quadratic, respectively). The analyses were done using the statistical pack program SAS Version 6 (1990) (SAS/STAT-SAS Institute Inc. Cary, NC-USA) in an IBM 9276 computer.

\section{RESULTS AND DISCUSSION}

All the factors - temperature (T), culture days $(\mathrm{C})$, strains $(\mathrm{L})$, and moisture content $(\mathrm{U})$ - herein evaluated showed relevant importance to the production of the toxins. The majority of the interactions between factors also influenced the production of toxins, except for the interactions of culture days with strains (CS) and culture days with different moisture contents (CU). The interaction between different utilized temperatures, culture days and strains (TCL) exhibited meaningful influence on $\mathrm{FB}_{1}$ production, however this did not occur in $\mathrm{FB}_{2}$ production. Table 2 
Table 2. Global analysis of variance on $\mathrm{FB}_{1}$ and $\mathrm{FB}_{2}$ production data suitably transformed into decimal log scale.

\begin{tabular}{|c|c|c|c|c|c|c|c|}
\hline \multirow{2}{*}{$\begin{array}{c}\text { Variation } \\
\text { causes }\end{array}$} & \multirow{2}{*}{$\begin{array}{c}\text { Freedom } \\
\text { degrees }\end{array}$} & \multicolumn{2}{|c|}{ Mean square } & \multicolumn{2}{|c|}{$\mathrm{F}$} & \multicolumn{2}{|c|}{ Significance level } \\
\hline & & $\mathrm{FB}_{1}$ & $\mathrm{FB}_{2}$ & $\mathrm{FB}_{1}$ & $\mathrm{FB}_{2}$ & $\mathrm{FB}_{1}$ & $\mathrm{FB}_{2}$ \\
\hline $\mathrm{T}^{*}$ & 2 & 28.68 & 31.04 & 306.39 & 292.37 & 0.0001 & 0.0001 \\
\hline $\mathrm{C}^{* * *}$ & 4 & 22.91 & 24.50 & 244.81 & 230.82 & 0.0001 & 0.0001 \\
\hline $\mathrm{L} * * *$ & 2 & 0.90 & 0.93 & 9.58 & 8.75 & 0.0001 & 0.0003 \\
\hline $\mathrm{U} * * * *$ & 2 & 3.91 & 4.50 & 41.81 & 42.36 & 0.0001 & 0.0001 \\
\hline $\mathrm{TC}$ & 8 & 1.36 & 1.08 & 14.57 & 10.22 & 0.0001 & 0.0001 \\
\hline $\mathrm{CU}$ & 8 & 1.52 & 1.57 & 16.19 & 14.75 & 0.0001 & 0.0001 \\
\hline $\mathrm{CL}$ & 8 & 0.19 & 0.17 & 1.99 & 1.57 & 0.0520 & 0.1399 \\
\hline LU & 4 & 0.14 & 0.11 & 1.47 & 0.99 & 0.2142 & 0.4157 \\
\hline TCL & 16 & 0.24 & 0.14 & 2.53 & 1.99 & 0.0020 & 0.2127 \\
\hline TCU & 16 & 0.72 & 0.59 & 7.67 & 5.54 & 0.0001 & 0.0001 \\
\hline VC $(\%)$ & & 11.99 & 15.01 & & & & \\
\hline $\mathrm{R}^{2}$ & & 0.95 & 0.94 & & & & \\
\hline
\end{tabular}

* T-Temperature; $* *$ C-Culture days; ${ }^{* * *} \mathrm{~L}-\mathrm{Strain} ;{ }^{* * * *}$ U-Moisture content; $* * * * \bar{X}$-Mean of yielded fumonisins $(\mu \mathrm{g} / \mathrm{g})$. Values without logarithmic transformation.

also shows that the average yield of $\mathrm{FB}_{1}$ produced was quite superior to that of $\mathrm{FB}_{2}$, this latter representing, approximately, $31.1 \%$ of the total fumonisins.

In relation to the averages of two repetitions of the 135 treatments of $\mathrm{FB}_{1}$ and $\mathrm{FB}_{2}$ production, a great variation in the amount of fumonisins produced was noted. The minimal and maximal productions of $\mathrm{FB}_{1}$ were $0.25 \mu \mathrm{g} / \mathrm{g}$ and $5515.45 \mu \mathrm{g} / \mathrm{g}$, respectively.

Concerning $\mathrm{FB}_{2}$, the minimal and maximal concentrations were of $0.15 \mu \mathrm{g} / \mathrm{g}$ and $3032.10 \mu \mathrm{g} / \mathrm{g}$, respectively. So, toxin production was obtained under all the conditions evaluated in the present experiment.

The concentration of fumonisins yielded under laboratory conditions is usually higher than toxins produced naturally. Accordingly, the average amounts of the two toxins produced during the experiment, $1345.38 \mu \mathrm{g} / \mathrm{g}$ and $606.37 \mu \mathrm{g} / \mathrm{g}$ of $\mathrm{FB}_{1}$ and $\mathrm{FB}_{2}$, respectively, were quite superior to those produced naturally, as reported by several authors $(9,23,30,32)$, who verified maximal concentrations up to $330 \mu \mathrm{g} / \mathrm{g}$ of $\mathrm{FB}_{1}$. This fact may be attributed to the culture conditions maintained in laboratory, where one has worked with the samples grow under controlled parameters and in previously autoclaved culture medium, facilitating therefore the growth of the inoculated fungi, corroborated by absence of concurrent fungal growth.

Similar concentrations were achieved by Schumacher et al. (29), $4360 \mu \mathrm{g} / \mathrm{g}$ of FB 1 ; and Roos et al. (26), who obtained up to
2350 and $320 \mu \mathrm{g} / \mathrm{g}$ of $\mathrm{FB}_{1}$ and $\mathrm{FB}_{2}$, respectively. On the other side, less toxins were produced than that reported by Holcomb et al. (10), who determined more than $10000 \mu \mathrm{g} / \mathrm{g}$ of FB ${ }_{1}$. It is noteworthy to point out here that after the culture period, the fungal cultures were autoclaved for $5 \mathrm{~min}$ and dried at $45^{\circ} \mathrm{C}$ for 15 hours. According to researches done by Dupuy et al. (7) and Jackson et al. (11), fumonisins are degraded at high temperatures. When exposed to $75^{\circ} \mathrm{C}$ for 8 uninterrupted hours, for example, they loss $c a .50 \%$ of activity. Consequently, one may corelate here the possible degradation to autoclaving and drying of the cultures.

\section{Fumonisin production as a function of the moisture of the fungal culture}

In the study analysis of the effect of the moisture content in corn on fumonisin production (Fig. 1), it was observed that the toxin yield increased of concomitantly to the moisture content increase, at $20^{\circ} \mathrm{C}$ and $25^{\circ} \mathrm{C}$. At $30^{\circ} \mathrm{C}$, an inverse effect was noted for both toxins, i.e. the increase of the moisture of the cultures led to a decrease in the amount of yielded toxins. This trend was observed for all strains, despite lack of statistical significance. The highest mean concentrations of $\mathrm{FB}_{1}$ and $\mathrm{FB}_{2}$ were yielded less than $42 \%$ moisture content, at $25^{\circ} \mathrm{C}$, especially for strain 113F.

According to several authors $(2,13)$, moisture content has a fundamental importance for fumonisin production, once low 
concentrations occur in cereals stored at moisture content lower than $22 \%$. In this work, the moisture content significantly in the amounts of produced fumonisins. The moisture content presented significant interaction with other factors, fact that did not take place with different strains which exhibited the same response to the same moisture content in the substrate.

\section{Fumonisin production as a function of the temperature of the fungal culture}

The influence of the temperature on fumonisin production may be observed in Fig. 2. The highest toxin prodution was obtained in cultures at $25^{\circ} \mathrm{C}$. At $20^{\circ} \mathrm{C}$, the production decreased and the lowest yields were observed in cultures at $30^{\circ} \mathrm{C}$. The ideal temperatures for $\mathrm{FB}_{1}$ production, calculated by regression, were of $24.3,24.7$ and $24.5^{\circ} \mathrm{C}$ for the strains LAMIC 2999/96, NRRL 13616 and 113F, respectively. From these data, the estimated optimal mean temperature for the $\mathrm{FB}_{1}$ production was $24.5^{\circ} \mathrm{C}\left( \pm 2^{\circ} \mathrm{C}\right)$. The same evaluations were done regarding $\mathrm{FB}_{2}$ production, and the ideal temperatures were of 24.2, 24.1 and $24.3^{\circ} \mathrm{C}$ for the strains LAMIC 2999/96, NRRL 13616 and $113 \mathrm{~F}$, respectively. The optimal mean temperature for the production of this toxin was $24.2^{\circ} \mathrm{C}\left( \pm 2^{\circ} \mathrm{C}\right)$.

In the interaction between temperature and moisture, the amount of the yielded toxins increased with the increase of the culture days, as evidenced by a greater average yield under different moisture contents in 60-day-old cultures.

Alberts et al. (1) studied the adaptation of Fusarium moniliforme to different temperatures. They concluded that this fungus grows better at $25^{\circ} \mathrm{C}$ than at $20^{\circ} \mathrm{C}$. Its lowest growth was ascertained at $30^{\circ} \mathrm{C}$. In our research, the production of fumonisins followed the same temperature parameters adopted by the above cited researchers. Low concentrations of these toxins were yielded at $30^{\circ} \mathrm{C}$, probably due to the slow growth of the fungus. Measurements of its growth was not emphasized in our experiments. At $20^{\circ} \mathrm{C}$, there were proportioned high yields of fumonisins, yet highest one was obtained at $25^{\circ} \mathrm{C}$.

In our work, the ideal temperatures found for fumonisins production $\left(24.5^{\circ} \mathrm{C}\right.$ and $24.2^{\circ} \mathrm{C}$ for $\mathrm{FB}_{1}$ and $\mathrm{FB}_{2}$, respectively), diverge from those reported by other authors, $\left(27^{\circ} \mathrm{C}\right.$ and $\left.28^{\circ} \mathrm{C}\right)$ $(37,39)$. However, our results are similar to those described by other authors $(10,14)$ utilizing the temperature of $25^{\circ} \mathrm{C}$.

\section{Fumonisin production as a function of the fungal strain utilized in cultures}

In Fig. 3, it may be observed that the strains show a very similar behavior at same temperature. The interaction of these two factors with the fungal culture time presented a larger output of toxins in 60 -day-old cultures at $25^{\circ} \mathrm{C}$. The largest total output was obtained by strain LAMIC $2999 / 96$ cultured at $25^{\circ} \mathrm{C}$ for 60 days. However, the best mean production occurred with strain $113 \mathrm{~F}$, at $25^{\circ} \mathrm{C}$. A similar behavior was noted for $\mathrm{FB}_{2}$, when a larger mean production was observed at $25^{\circ} \mathrm{C}$ by strain $113 \mathrm{~F}$, which also yielded the largest amount of $\mathrm{FB}_{2}$ at 60 days of culture at the same temperature.

The strains exhibited total fumonisin production in similar amounts but, when the production of each strain was assessed without the interaction with the effects of temperature, moisture and culture periods, their differences were highly significant, as shown in Table 2 .

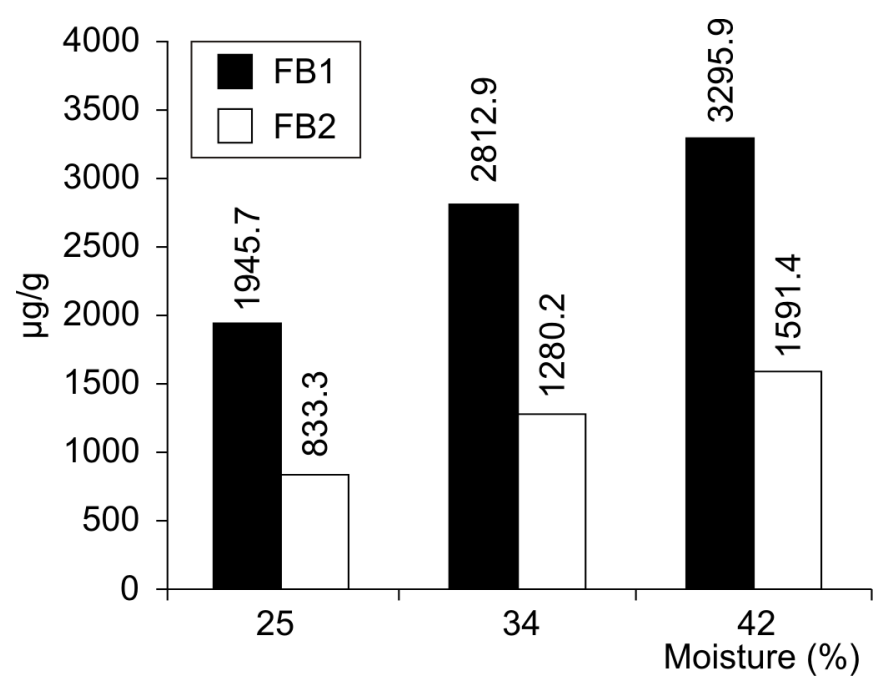

Figure 1. Mean fumonisin output as a function of the culture moisture content.

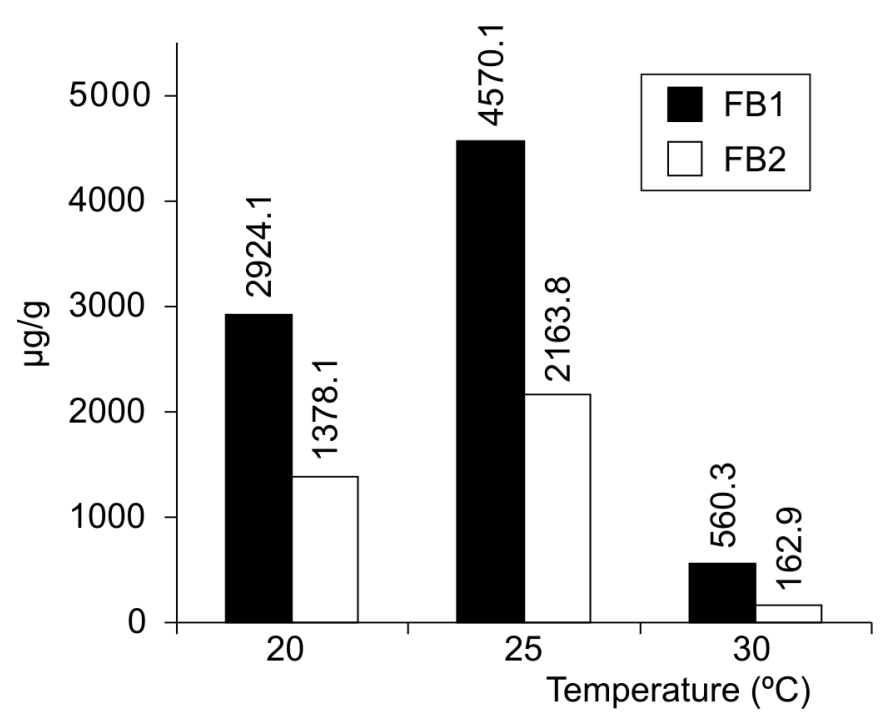

Figure 2. Mean fumonisin output as a function of culture temperature. 
Fumonisin production as a function of fungal culture time

In Fig. 4, the effect of the fungal culture period on fumonisin prodution may be observed. The toxin production increased with the increase of the culture time. The largest production was obtained in strain $113 \mathrm{~F}$ cultured for 60 days under $42 \%$ moisture content. For the three strains, $\mathrm{FB}_{1}$ production reached the maximum of $44.3 \mu \mathrm{g} / \mathrm{g} /$ day in a period of 60 days. In relation to $\mathrm{FB}_{2}$ production, the maximal mean output occurred on 45 days of culture, especially for strain $113 \mathrm{~F}$. The toxin prodution was linear, deriving a theoretical mean increment of $32.1 \mu \mathrm{g} / \mathrm{g} /$

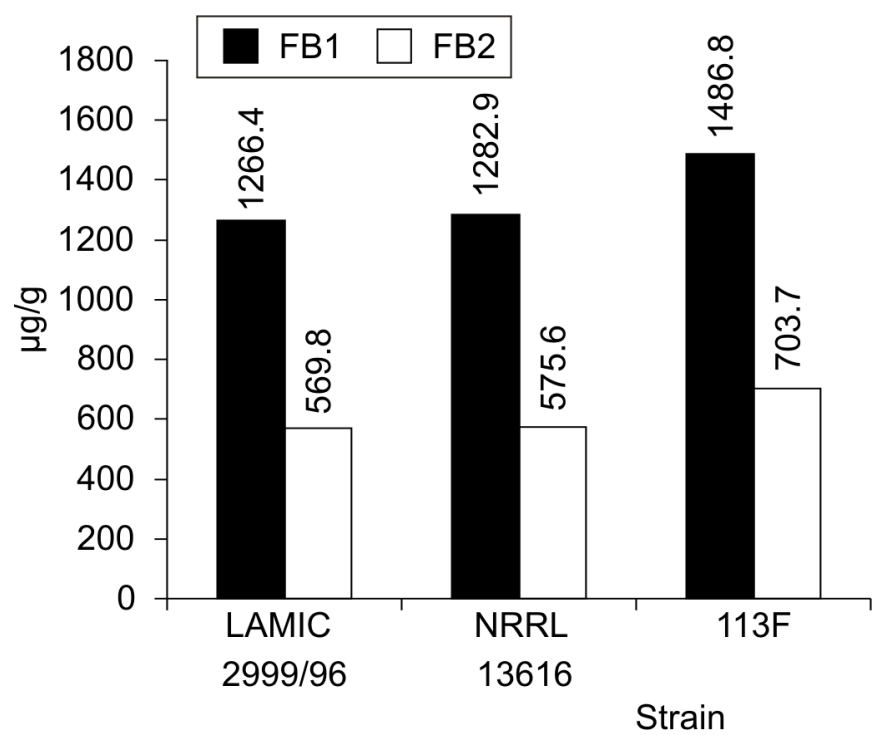

Figure 3. Mean fumonisin output as a function of the strain.

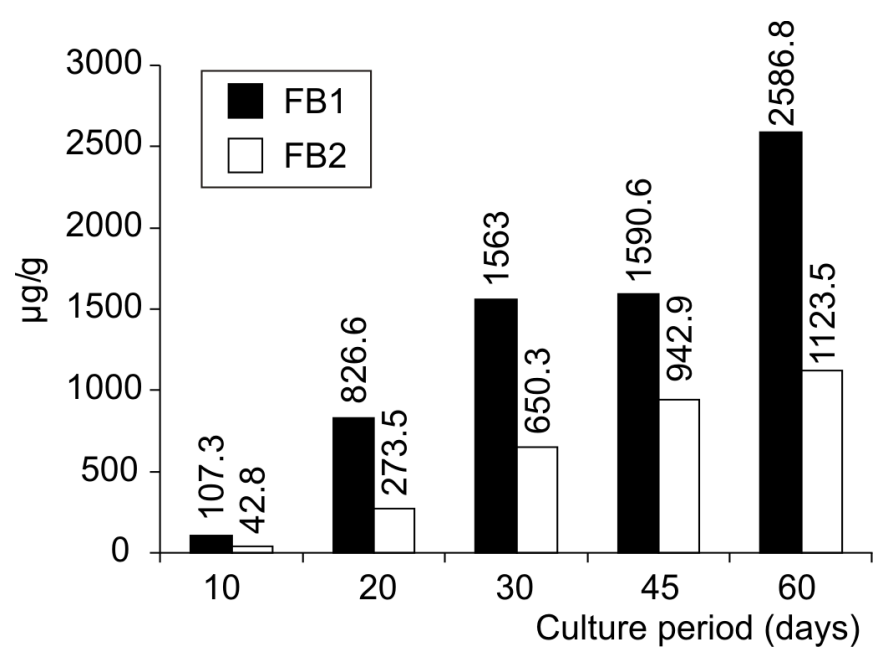

Figure 4. Mean fumonisin output as a function of the fungal culture time. day in the three strains, up to the 45 days of culture at the conditions employed in this work.

The fungal culture period has great importance for production of $\mathrm{FB}_{1}$ and $\mathrm{FB}_{2}$ as well. In 10-day-old cultures, the production was lowest, yet in sufficient amount to induce the characteristic pathologies in all species susceptible to these mycotoxins. With the increase of culture periods, the mean production of the toxins raised continually.

\section{ACKNOWLEDGMENTS}

We thank the Conselho Nacional de Desenvolvimento Científico e Tecnológico (Brasil) for the financial support to this work. We also wish to thank Dr. Elisa Yoko Hirooka, professor at the Universidade Estadual de Londrina - PR, Brazil, for providing strain 113F of Fusarium moniliforme.

\section{RESUMO}

Produção de fumonisinas por cepas de Fusarium moniliforme de acordo com a temperatura, umidade e tempo de cultura

Produção de fumonisinas $\mathrm{B}_{1}\left(\mathrm{FB}_{1}\right)$ e $\mathrm{B}_{2}\left(\mathrm{FB}_{2}\right)$ a partir de duas cepas brasileiras (LAMIC 2999/96 e 113F) e uma cepa americana (NRRL 13616) de Fusarium moniliforme foi avaliada em culturas de laboratório submetidas a diferentes temperaturas $\left(20,25\right.$ e $\left.30^{\circ} \mathrm{C}\right)$ e a diferentes teores de umidade $(25,34$ e $42 \%)$ em substrato de milho. As culturas foram realizadas em períodos de 10, 20, 30, 45 e 60 dias, totalizando 135 tratamentos com duas repetições para cada um. As fumonisinas foram extraídas com acetonitrila/água. A limpeza foi realizada empregando cartuchos de sílica $\mathrm{C}_{18}$ encapada $\left(\mathrm{C}_{18 \mathrm{ec}}\right)$ e a derivação com $o$-ftalodialdeído foram realizadas por um sistema processador automático de amostras (ASPEC), seguidas por quantificação das toxinas por CLAE. A produção de fumonisinas variou muito, atingindo rendimentos médios de 0,25 a $5515,45 \mu \mathrm{g} / \mathrm{g}$ de $\mathrm{FB}_{1}$ e de 0,15 a $3032,10 \mu \mathrm{g} / \mathrm{g}$ de $\mathrm{FB}_{2}$. Neste trabalho, os fatores como cepa, temperatura, umidade e dias de cultura fúngica foram avaliados, e todos estes influenciaram nas quantidades de fumonisinas produzidas. As mais altas produções de $\mathrm{FB}_{1}$ foram obtidas pela cepa $113 \mathrm{~F}$ nas seguintes condições: teor de umidade de 34\%, 60 dias de cultura, temperatura de $25^{\circ} \mathrm{C}$. A maior produção média de $\mathrm{FB}_{2}$ foi obtida pela mesma cepa com culturas durante 45 dias, a um teor de umidade de $42 \%$, à temperatura de $25^{\circ} \mathrm{C}$. A temperatura ideal para produção de fumonisinas foi calculada por meio de análise de regressão, sendo $24,5^{\circ} \mathrm{C}$ e $24,3^{\circ} \mathrm{C}\left( \pm 2^{\circ} \mathrm{C}\right)$ para $\mathrm{FB}_{1} \mathrm{e}$ $\mathrm{FB}_{2}$, respectivamente.

Palavras-chave: Fungos, Fusarium moniliforme, micotoxinas, fumonisinas, fatores abióticos. 


\section{REFERENCES}

1. Alberts, J.F.; Gelderblom, W.C.A.; Thiel, P.G.; Marasas, W.F.O.; Van Schalkwyk, D.J.; Behrend, Y. Effects of temperature and incubation period on production of fumonisin $\mathrm{B}_{1}$ by Fusarium moniliforme. Appl. Environ. Microbiol., 56: 1729-33, 1990.

2. Cahagnier, B.; Melcion, D.; Richard-Molard, D. Growth of Fusarium moniliforme and its biosynthesis of fumonisin $\mathrm{B}_{1}$ on maize grain as a funtion of different water activities. Lett. Appl. Microbiol., 20: 247-251, 1995 .

3. Casteel, S.W.; Turk, J.R.; Cowart, R.P.; Rottinghaus, G.E. Chronic toxicity of fumonisin in weanling pigs, J. Vet. Diagn. Invest., 5: 413417, 1993.

4. Chen, J.; Mirocha, C.J.; Xie, W.; Hotgge, L.; Olson, D. Production of the mycotoxin fumonisin $\mathrm{B}_{1}$ by Alternaria alternata f. sp. Lycopersici. Appl. Environ. Microbiol., 58: 3928-3931, 1992.

5. Chu, F.S.; Li, G.Y. Simultaneous occurrence of fumonisin $B_{1}$ and other mycotoxins in moldy corn collected from the People's Republic of China in regions with high incidences of esophageal cancer. Appl. Environ. Microbiol., 60: 847-852, 1994.

6. Dias, S.M.C.; Mallozzi, M.A.B.; Corrêa, B.; Israel, W.M.; Gonçalez, E. Fluorimetric quantitation of opa-derivatives of fumonisins $B_{1}$ and $\mathrm{B}_{2}$ in corn and Fusarium moniliforme culture extracts. Arq. Inst. Biol., 66: 69-75, 1999.

7. Dupuy, J.; Le Bars, P.; Boudra, H.; Le Bars, J. Termoestability of fumonisin $\mathrm{B}_{1}$, a mycotoxin from Fusarium moniliforme, in corn. Appl. Environ. Microbiol., 59: 2864-2867, 1993.

8. Hennigen, M.R.; Sanchez, S.; Di Benedetto, N.M.; Longhi, A.; Torroba, J.E.; Valente Soares, L.M. Fumonisin level in commercial corn products in Buenos Aires, Argentina. Food Addit. Contam., 17: $55-58,2000$.

9. Hirooka, E.Y.; Yamaguchi, M.M.; Aoyama, S.; Sugiura, Y.; Ueno, Y. The natural occurrence of fumonisins in Brazilian corn kernels. Food Addit. Contam., 13: 173-183, 1996.

10. Holcomb, M.; Sutherland, J.B.; Chiarelli, M.P.; Korfmacher, W.A.; Thompson Jr., H.C.; Lay Jr., J.O.; Hankins, L.J.; Cerniglia, C.E. HPLC and FAB mass spectrometry analysis of fumonisins $B_{1}$ and $B_{2}$ produced by Fusarium moniliforme on food substrates. J. Agric. Food Chem., 41: 357-60, 1993.

11. Jackson, L.S.; Hlywka, J.J.; Senthil, K.R.; Bullerman, L.B. Effect of thermal processing on the stability of fumonisins. Adv. Exp. Med. Biol., 392: 345-353, 1996.

12. Kellerman, T.S.; Marasas, W.F.O.; Thiel, P.G.; Gelderblom, W.C.A.; Cawood, M.; Coetzer, J.A.W. Leukoencephalomalacia in two horses induced by oral dosing of fumonisin $\mathrm{B}_{1}$. Onderstepoort J. Vet. Res., 57: 269-275, 1990.

13. Le Bars, J.; Le Bars, P.; Dupuy, J.; Boudra, H. Biotic and abiotic factors in fumonisin $\mathrm{B}_{1}$ production and stability. J. Assoc. Off. Anal. Chem., 77: 517-521, 1994.

14. Ledoux, D.R.; Brown, T.P.; Weibking, T.S.; Rottinghaus, G.E. Fumonisin toxicity in broiler chicks. J. Vet. Diagn. Invest., 4: 330333, 1992

15. Mallmann, C.A.; Santurio, J.M.; Dilkin P. Equine leukoencephalomalacia associated with ingestion of corn contaminated with fumonisin $\mathrm{B}_{1}$. Rev. Microbiol., 30: 249-252, 1999.

16. Marín, S.; Sanchis, V.; Vinas, I.; Canela, R.; Magan, N. Effect of water activity and temperature on growth and fumonisin $\mathrm{B}_{1}$ and $\mathrm{B}_{2}$ production by Fusarium proliferatum and $F$. moniliforme on maize grain. Lett. Appl. Microbiol., 21: 298-301, 1995.

17. Marín, S.; Sanchis, V.; Magan, N. Water activity, temperature, and $\mathrm{pH}$ effectes on growth of Fusarium moniliforme and Fusarium proliferatum isolates from maize. Can. J. Microbiol., 41: 1063$1070,1995$.
18. Murphy, P.A.; Rice, L.G.; Ross, P.F. Fumonisin $\mathrm{B}_{1}, \mathrm{~B}_{2}$ and $\mathrm{B}_{3}$ content of Iowa, Wisconsin, and Illinois corn and corn screenings. J. Agric. Food Chem., 41: 263-266, 1993.

19. Nelson, P.E.; Plattner, R.D.; Shackelford, D.D.; Dejardins, A.E. Production of fumonisins by Fusarium moniliforme strains from various substrates and geographic areas. Appl. Environ. Microbiol., 57: 2410-2412, 1991.

20. Norred, W.P. Fumonisins-mycotoxins produced by Fusarium moniliforme. J. Toxicol. Environ. Health, 38: 309-328, 1993.

21. Orsi, R.B.; Corrêa, B.; Pozzi, C.R.; Schammass, E.A.; Nogueira, J.R.; Dias, S.M.C.; Mallozzi, M.A.B. Mycoflora and occurrence of fumonisins in freshly harvested and stored hybrid maize. J. Stor. Prod. Res., 36: 75-84, 2000.

22. Osweiler, G.D.; Ross, P.F.; Wilson, T.M.; Nelson, P.E.; Witte, S.T.; Carson, T.L.; Rice, L.G.; Nelson, H.A. Characterization of an epizootic of pulmonary edema in swine associated with fumonisin in corn screenings. J. Vet. Diagn. Invest., 4: 53-59, 1992.

23. Piñeiro, M.S.; Silva G.E.; Scott, P.M.; Lawrence, A.L.; Stack, M.E. Fumonisin levels in Uruguayan corn products. J. Assoc. Off. Anal. Chem., 80: 825-828, 1997.

24. Rheeder, J.P.; Marasas, W.F.O.; Thiel, P.G. Fusarim moniliforme and fumonisins in corn in relation to human esophageal cancer in Transkei. Phytopathology, 82: 253-257, 1992.

25. Rice, L.G.; Ross, P.F.; Dejong, J.; Plattner, R.D.; Coats, J.R. Evaluation of a liquid chromatographic method for the determination of fumonisins in corn, poultry feed, and Fusarium culture material. J. Assoc. Off. Anal. Chem., 78: 1002-1009, 1995.

26. Ross, P.F.; Nelson, P.E.; Richard, J.L.; Osweiler, G.D.; Rice, L.G.; Plattner, R.D.; Wilson, T.M. Production of fumonisins by Fusarium moniliforme and Fusarium proliferatum isolates associated with equine leukoencephalomalacia and a pulmonary edema syndrome in swine. Appl. Environ. Microbiol., 56: 3224 3226, 1990

27. Ross, P.F.; Rice, L.G.; Platter, R.D.; Osweiler, G.D.; Wilson, T.M.; Owens, D.L.; Nelson, H.A.; Richard, J.L. Concentrations of fumonisin $\mathrm{B}_{1}$ in feeds associated with animal health problems. Mycopathologia, 114: 129-35, 1991.

28. Ryu, D.; Munimbazi, C.; Bullerman, L.B. Fumonisin B Production by Fusarium moniliforme and Fusarium proliferatum as affected by cycling temperatures. J. Food Protect., 62: 1456$1460,1999$.

29. Schumacher, J.; Mullen, J.; Shelby, R.; Lenz, S.; Ruffin, D.C.; Kemppainen, B.W. An investigation of the role of Fusarium moniliforme in duodenitis/proximal jejunitis of horses. Vet. Human Toxicol., 37: 39-45, 1995.

30. Shephard, G.S.; Thiel, P.G.; Stockenstrom, S.; Sydenham, E.W. Wordwide survey of fumonisin contamination of corn and cornbased products. J. Assoc. Off. Anal. Chem., 79: 671-687, 1996.

31. Stack, M.E. \& Eppley, R.M. Liquid chromatographic determination of fumonisins $\mathrm{B}_{1}$ and $\mathrm{B}_{2}$ in corn and corn products. J. Assoc. Off. Anal. Chem., 75: 834-37, 1992.

32. Sydenham, E.W.; Marasas, W.F.O.; Shephard, G.S.; Thiel, P.G.; Hirooka, E.Y. Fumonisins concentrations in Brazilian feeds associated with field outbreaks of confirmed and suspected animal mycotoxicoses. J. Agric. Food Chem., 40: 994-997, 1992.

33. Sydenham, E.W.; Shephard, G.S.; Thiel, F.G.; Bird, C.; Miller, B.M Determination of fumonisins in corn: evaluation of competitive immunoassay and HPLC techniques. J. Agric. Food Chem., 44: 159-164, 1996.

34. Sydenham, E.W.; Shephard, G.S.; Thiel, P.G.; Marasas, W.F.O.; Rheeder, J.P.; Peralta-Sanhueza, C.A.; Gonzalez, H.H.L.; Resnik, S.L. Fumonisins in Argentinian field-trial corn. J. Agric. Food. Chem., 41: 891-895, 1993.

35. Sydenham, E.W.; Thiel, P.G.; Marasas, W.F.O.; Shephard, G.S.; Schalkwyk, D.J.; Kock, K.R. Natural occurrence of some Fusarium 


\section{P. Dilkin et al.}

mycotoxins in corn from low and high esophageal cancer prevalence areas of the Transkei, southern Africa. J. Agric. Food Chem., 38: 767-771, 1990

36. Thiel, P.G.; Marasas, W.O.F.; Sydenham, E.W.; Shephard, G.S.; Gelderblom W.C.A.; Nieuwenhuis, J.J. Survey of fumonisin production by Fusarium species. Appl. Environ. Microbiol., 57: 1089-1093, 1991.

37. Tseng, T.; Lee, K.; Deng, T.; Liu, C.; Huang, J. Production of fumonisin by Fusarium species of Taiwan. Mycopathologia, 130: 117-21, 1995.
38. Visconti, A. \& Doko, M.B. Survey of fumonisin production by Fusarium isolated from cereals in Europe, J. Assoc. Off. Anal. Chem., 77: 546-550, 1994.

39. Weibking, T.S.; Ledoux, D.R.; Brown, T.P.; Rottinghaus, G.E. Fumonisin toxicity in turkey poults. J. Vet. Diagn. Invest., 5: 75-83, 1993.

40. Yoo, H.S.; Norred, W.P.; Wang, E.; Merrill Jr.; A.H.; Riley, R.T. Fumonisin inhibition of de novo sphingolipid biosynthesis and cytotoxicity are correlated in LLC-PK 1 cells. Toxicol. Appl. Pharmacol., 114: 9-15, 1992. 